\title{
Indoor radon monitoring in the Mandi district of Himachal Pradesh, India, for health hazard assessment
}

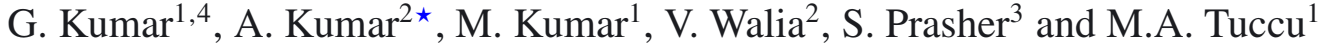 \\ 1 Department of Physics, Lovely Professional University, Phagwara, Punjab 144411, India. \\ 2 National Center for Research on Earthquake Engineering, NARL, Taipei 106, Taiwan. \\ 3 Department of Physics, Kanya Maha Vidyalaya, Jalandhar, Punjab 144004, India. \\ ${ }^{4}$ Govt. College Sarkaghat, Mandi, Himachal Pradesh 175024, India.
}

Received 16 September 2015 - Accepted 28 October 2015

\begin{abstract}
In the present study, indoor radon equilibrium equivalent concentration monitoring was carried out using Solid-State Nuclear Track Detectors in some residential areas of the Mandi district, Himachal Pradesh, India. The average value of the indoor radon equilibrium equivalent concentration in the study area was found to be $94 \mathrm{~Bq} \mathrm{~m}^{-3}$, with an annual effective dose of $1.61 \mathrm{mSv}$. The average value of the indoor radon equilibrium equivalent concentration in the studied areas was found to be higher than the world average indoor radon value of $40 \mathrm{~Bq} \mathrm{~m}^{-3}$ but lower than the value of the action level $300 \mathrm{~Bq} \mathrm{~m}^{-3}$, except for two locations.
\end{abstract}

Keywords: LR-115 / indoor radon / health hazard / Himachal Pradesh

\section{Introduction}

Radon measurements are essential to assess radon concentrations in homes, as studies in Europe, North America and Asia provide strong evidence that the cancer risk increases proportionally with the increasing concentration of radon (WHO, 2009). The primary route of exposure to radon and its progeny is inhalation. Radiation exposure from radon is indirect. When radon gas is inhaled, the alpha particles emitted interact with the biological tissue in the lungs, leading to DNA damage, and can greatly increase the concentration of mutant cells available for the development of cancer.

Numerous measurements of radon activity concentrations in different countries have been published in recent years (UNSCEAR, 2000; Kávási et al., 2010). Though indoor radon data are available for the Hamirpur, Kullu and Una districts of Himachal Pradesh (Kumar et al., 1994; Singh et al., 2001), the Mandi district has not been studied for environmental radon so far. So, in order to generate a database, a survey was carried out for the first time for the measurement of the indoor radon equilibrium equivalent concentration in some residential areas of the Mandi district, Himachal Pradesh, India. It is situated in the Western Himalayas between $31^{\circ}-13^{\prime}-20^{\prime \prime}$ and $32^{\circ}-04^{\prime}-30^{\prime \prime}$ North latitude and $76^{\circ}-37^{\prime}-20^{\prime \prime}$ and $77^{\circ}-23^{\prime}-15^{\prime \prime}$ East longitude.

\section{Methodology}

In the present study, LR-115 films (size $1.5 \mathrm{~cm} \times 1.5 \mathrm{~cm}$ ) were placed on glass slides at about $2 \mathrm{~m}$ height from the

\footnotetext{
^ kumararvind79@hotmail.com
}

ground such that the sensitive portion of the film was exposed to the air. After an exposure of 90 days, the detectors were subjected to chemical processing in a $10 \mathrm{M}$ analytical-grade sodium hydroxide solution at $60{ }^{\circ} \mathrm{C}$, for $90 \mathrm{~min}$., in a constant temperature water bath to enlarge the latent tracks. After the etching, the detectors were washed for $30 \mathrm{~min}$. After a few minutes of drying in the air, the detectors were counted for tracks using an optical microscope (at $400 \times$ magnification). Then, the tracks were converted into the concentration of the radon equilibrium equivalent by the following conversion 0.02 tracks cm ${ }^{-2}$ day $^{-1}=1 \mathrm{~Bq} \mathrm{~m}^{-3}$ (Eappen and Mayya, 2004). The radon exposure is determined on the basis of the ICRP-adopted conversion convention model (Chen, 2005).

\section{Results and discussion}

The observed values of the indoor radon equilibrium equivalent concentration in three different regions: Sarkaghat, Jogindernagar and Mandi-Sundernagar of the Mandi district, Himachal Pradesh, India, are shown in Tables 1 and 2, respectively. The indoor radon equilibrium equivalent concentration varies from $17 \pm 5 \mathrm{~Bq} \mathrm{~m}^{-3}$ to $533 \pm 41 \mathrm{~Bq} \mathrm{~m}^{-3}$, with the average for the whole year (annual average) being $94 \mathrm{~Bq} \mathrm{~m}^{-3}$. Houses in Sarkaghat had an average indoor radon equilibrium equivalent concentration for the whole year of $101 \mathrm{~Bq} \mathrm{~m}^{-3}$. The Mandi-Sundernagar region was observed to have an average radon equilibrium equivalent concentration of $124 \mathrm{~Bq} \mathrm{~m}^{-3}$, whereas the average value of the Jogindernagar region was $56 \mathrm{~Bq} \mathrm{~m}^{-3}$. The average value of the indoor radon equilibrium equivalent concentration in the three different regions 
Table 1. Indoor radon equilibrium equivalent concentration observed in the Sarkaghat and Jogindernagar regions.

\begin{tabular}{|c|c|c|c|c|c|c|}
\hline \multirow[b]{3}{*}{ House no. } & \multicolumn{5}{|c|}{ Sarkaghat region } & \multirow[b]{3}{*}{ Effective dose $\left(\mathrm{mSv} \mathrm{y}^{-1}\right)$} \\
\hline & \multicolumn{5}{|c|}{ Radon concentration $\left(\mathrm{Bq} \mathrm{m}^{-3}\right)$} & \\
\hline & $\begin{array}{l}\text { Oct - Dec, } \\
2012\end{array}$ & $\begin{array}{c}\text { Jan - March, } \\
2013\end{array}$ & $\begin{array}{l}\text { April - June, } \\
2013\end{array}$ & $\begin{array}{c}\text { July - Sept, } \\
2013\end{array}$ & $\begin{array}{c}\mu \pm \sigma \\
(\text { Average } \pm \text { Stdev })\end{array}$ & \\
\hline 1 & 194 & 165 & 141 & 173 & $168 \pm 22$ & 2.89 \\
\hline 2 & 96 & 109 & 103 & 121 & $107 \pm 11$ & 1.84 \\
\hline 3 & 118 & 104 & 112 & 116 & $113 \pm 6$ & 1.94 \\
\hline 4 & 62 & 43 & 47 & 54 & $52 \pm 8$ & 0.89 \\
\hline 5 & 65 & 40 & 51 & 98 & $64 \pm 25$ & 1.09 \\
\hline 6 & 36 & 32 & 38 & 32 & $35 \pm 3$ & 0.59 \\
\hline 7 & 38 & 29 & 33 & 49 & $37 \pm 9$ & 0.64 \\
\hline 8 & 44 & 18 & 27 & 36 & $31 \pm 11$ & 0.54 \\
\hline 9 & 78 & 144 & 167 & 92 & $120 \pm 42$ & 1.78 \\
\hline 10 & 524 & 592 & 498 & 519 & $533 \pm 41$ & 9.17 \\
\hline 11 & 38 & 58 & 42 & 38 & $44 \pm 10$ & 0.76 \\
\hline 12 & 82 & 98 & 101 & 96 & $94 \pm 8$ & 1.6 \\
\hline 13 & 42 & 48 & 46 & 42 & $45 \pm 3$ & 0.77 \\
\hline 14 & 32 & 36 & 41 & 36 & $36 \pm 4$ & 0.62 \\
\hline 15 & 39 & 41 & 38 & 50 & $42 \pm 5$ & 0.72 \\
\hline \multicolumn{7}{|c|}{ Jogindernagar region } \\
\hline 1 & 54 & 48 & 36 & 54 & $48 \pm 8$ & 0.83 \\
\hline 2 & 164 & 174 & 156 & 182 & $169 \pm 11$ & 2.90 \\
\hline 3 & 19 & 49 & 14 & 21 & $26 \pm 16$ & 0.44 \\
\hline 4 & 32 & 37 & 28 & 33 & $33 \pm 4$ & 0.56 \\
\hline 5 & 40 & 29 & 26 & 36 & $33 \pm 6$ & 0.56 \\
\hline 6 & 23 & 30 & 54 & 61 & $42 \pm 18$ & 0.72 \\
\hline 7 & 21 & 23 & 12 & 19 & $19 \pm 5$ & 0.32 \\
\hline 8 & 101 & 92 & 78 & 98 & $92 \pm 10$ & 1.59 \\
\hline 9 & 42 & 42 & 21 & 24 & $32 \pm 11$ & 0.55 \\
\hline 10 & 31 & 43 & 34 & 30 & $35 \pm 6$ & 0.59 \\
\hline 11 & 83 & 95 & 56 & 65 & $75 \pm 18$ & 1.29 \\
\hline 12 & 44 & 63 & 66 & 54 & $57 \pm 10$ & 0.98 \\
\hline 13 & 11 & 23 & 16 & 19 & $17 \pm 5$ & 0.30 \\
\hline 14 & 38 & 40 & 30 & 42 & $38 \pm 5$ & 0.65 \\
\hline 15 & 114 & 132 & 93 & 105 & $111 \pm 16$ & 1.91 \\
\hline 16 & 40 & 57 & 33 & 42 & $43 \pm 10$ & 0.74 \\
\hline 17 & 31 & 36 & 27 & 28 & $31 \pm 4$ & 0.52 \\
\hline 18 & 168 & 203 & 130 & 180 & $170 \pm 30$ & 2.93 \\
\hline 19 & 26 & 29 & 19 & 24 & $25 \pm 4$ & 0.42 \\
\hline
\end{tabular}

studied is higher than the world average indoor radon value of $40 \mathrm{~Bq} \mathrm{~m}^{-3}$ (UNSCEAR, 2000). However, the indoor radon equilibrium equivalent concentrations observed in the study areas were lower than the action level $300 \mathrm{~Bq} \mathrm{~m}^{-3}$ (ICRP, 2009), except for one house in the Sarkaghat region and one house in the Mandi-Sundernagar region (Tables 1 and 2).

The average value of the observed annual effective dose in the Sarkaghat region, Mandi-Sundernagar region and Jogindernagar region were found to be $1.72 \mathrm{mSv}, 2.14 \mathrm{mSv}$ and $0.97 \mathrm{mSv}$, respectively (Tables 1 and 2). The total mean annual estimated effective dose received by the public of the study area was $1.61 \mathrm{mSv}$. The average annual estimated effective dose is lower than the recommended action level of 3-10 $\mathrm{mSv} \mathrm{y}^{-1}$ (ICRP, 1993).

It was also observed that the values of the indoor radon equilibrium equivalent concentration were usually high in the Mandi-Sundernagar region as compared with the other regions of the study area. Since the radon concentration depends upon the uranium content in the soil, these high values may be attributed to the high uranium content in the soils of this region (Sharma et al., 2000) and low ventilation conditions. Moreover, the region also has a number of thermal springs, and a 
Table 2. Indoor radon equilibrium equivalent concentration observed in the Mandi-Sundernagar region.

\begin{tabular}{|c|c|c|c|c|c|c|}
\hline \multirow[b]{2}{*}{ House no. } & \multicolumn{5}{|c|}{ Radon concentration $\left(\mathrm{Bq} \mathrm{m}^{-3}\right)$} & \multirow[b]{2}{*}{ Effective dose $\left(\mathrm{mSv} \mathrm{y}^{-1}\right)$} \\
\hline & $\begin{array}{c}\text { Oct - Dec, } \\
2012\end{array}$ & $\begin{array}{c}\text { Jan - March, } \\
2013\end{array}$ & $\begin{array}{l}\text { April - June, } \\
2013\end{array}$ & $\begin{array}{c}\text { July - Sept, } \\
2013\end{array}$ & $\begin{array}{c}\mu \pm \sigma \\
(\text { Average } \pm \text { Stdev })\end{array}$ & \\
\hline 1 & 86 & 97 & 81 & 102 & $92 \pm 10$ & 1.57 \\
\hline 2 & 54 & 52 & 51 & 56 & $53 \pm 2$ & 0.92 \\
\hline 3 & 163 & 127 & 113 & 122 & $131 \pm 22$ & 2.26 \\
\hline 4 & 78 & 73 & 64 & 64 & $70 \pm 7$ & 1.20 \\
\hline 5 & 89 & 100 & 91 & 99 & $95 \pm 6$ & 1.63 \\
\hline 6 & 44 & 49 & 42 & 48 & $46 \pm 3$ & 0.79 \\
\hline 7 & 207 & 293 & 180 & 214 & $224 \pm 49$ & 3.84 \\
\hline 8 & 87 & 124 & 108 & 117 & $109 \pm 16$ & 1.88 \\
\hline 9 & 99 & 107 & 91 & 97 & $99 \pm 7$ & 1.69 \\
\hline 10 & 158 & 133 & 114 & 121 & $132 \pm 19$ & 2.26 \\
\hline 11 & 52 & 93 & 79 & 76 & $75 \pm 17$ & 1.29 \\
\hline 12 & 99 & 124 & 111 & 110 & $111 \pm 10$ & 1.90 \\
\hline 13 & 97 & 133 & 128 & 147 & $126 \pm 21$ & 2.17 \\
\hline 14 & 126 & 160 & 158 & 167 & $153 \pm 18$ & 2.63 \\
\hline 15 & 162 & 138 & 134 & 136 & $143 \pm 13$ & 2.45 \\
\hline 16 & 82 & 68 & 53 & 64 & $67 \pm 12$ & 1.15 \\
\hline 17 & 92 & 113 & 102 & 120 & $107 \pm 12$ & 1.84 \\
\hline 18 & 74 & 117 & 109 & 131 & $108 \pm 24$ & 1.85 \\
\hline 19 & 127 & 213 & 190 & 218 & $187 \pm 42$ & 3.22 \\
\hline 20 & 47 & 66 & 52 & 65 & $58 \pm 10$ & 0.99 \\
\hline 21 & 105 & 137 & 123 & 168 & $133 \pm 27$ & 2.29 \\
\hline 22 & 158 & 137 & 151 & 177 & $156 \pm 17$ & 2.68 \\
\hline 23 & 152 & 140 & 147 & 157 & $149 \pm 7$ & 2.56 \\
\hline 24 & 135 & 126 & 117 & 119 & $124 \pm 8$ & 2.14 \\
\hline 25 & 62 & 129 & 131 & 152 & $119 \pm 39$ & 2.04 \\
\hline 26 & 79 & 61 & 48 & 51 & $60 \pm 14$ & 1.03 \\
\hline 27 & 311 & 162 & 136 & 126 & $184 \pm 86$ & 3.16 \\
\hline 28 & 49 & 42 & 35 & 36 & $41 \pm 6$ & 0.70 \\
\hline 29 & 180 & 190 & 166 & 174 & $178 \pm 10$ & 3.05 \\
\hline 30 & 568 & 437 & 320 & 345 & $417 \pm 112$ & 7.18 \\
\hline
\end{tabular}

uranium mineralisation zone with high values of radon, uranium and deep originated gases which can be possible radon carriers (Walia et al., 2005; Cinti et al., 2009). However, the present study area is far away from these features and not influenced by it.

\section{Conclusions}

The average value of the indoor radon equilibrium equivalent concentration in the study area is higher than the world average indoor radon value, but lower than the action level except for two locations, and may not pose any significant threat to the public health. The difference in the average value of the observed radon equilibrium equivalent concentration in different parts of the study area may be due to differences in the radioactive contents of the soil.

\section{References}

Chen J. (2005) A Review of Radon Doses, Radiat. Prot. Manag. 22 (4), 27-31.

Cinti D., Pizzino L., Voltattorni N., Quattrocchi F., Walia V. (2009) Geochemistry of thermal waters along fault segments in the Beas and Parvati valleys (north-west Himalaya, Himachal Pradesh) and in the Sohna town (Haryana), India Geochem. J. 43 (2), 65-76.

Eappen K.P., Mayya Y.S. (2004) Calibration factors for LR-115 (Type-II) based radon thoron discriminating dosimeter, Radiat. Meas. 38 (1), 5-17.

ICRP (1993) International Commission on Radiological Protection. Protection Against Radon-222 at Home and at work, ICRP publication 65, Annals ICRP 23 (2). 
ICRP (2009) International Commission on Radiological Protection. Statement on Radon, ICRP Ref 00/902/09.

Kávási N., Somlai J., Szeiler G., Szabó B., Schafer I., Kovács T. (2010) Estimation of effective doses to cavers based on radon measurements carried out in seven caves of the Bakony Mountains in Hungary, Radiat. Meas. 45, 1068-1071.

Kumar J., Malhotra R., Singh J., Singh S. (1994) Radon measurements in dwellings in radioactive areas in Himachal Pradesh, India, using LR-115, plastic track detectors, Nucl. Geophys. 8 (6), 573-576.

Sharma M., Sharma Y.C., Basu B., Chhabra J., Gupta R.K., Singh J. (2000) Uranium mineralization in the sandstones of Dharamshala, Tileli area Mandi district, Himachal Pradesh, India, Curr. Sci. 78 (7), 897-899.
Singh S., Malhotra R., Kumar J., Singh L. (2001) Indoor radon measurements in dwellings of Kullu area, Himachal Pradesh, using solid state nuclear track detector, Radiat. Meas. 34, 505-508.

UNSCEAR (2000) United Nations Scientific Committee on Effects of Atomic Radiation sources and effects of Ionizing Radiation. Report to General Assembly, New York.

Walia V., Quattrocchi F., Virk H.S., Yang T.F., Pizzino L., Bajwa B.S. (2005) Radon, Helium and Uranium survey in some thermal springs located in NW Himalayas, India: mobilization by tectonic features or by geochemical barriers? J. Environ. Monit. 7, 850-855.

WHO (2009) Handbook on Indoor Radon. The World Health Organization (WHO).

Cite this article as: G. Kumar, A. Kumar, M. Kumar, V. Walia, S. Prasher, M.A. Tuccu. Indoor radon monitoring in the Mandi district of Himachal Pradesh, India, for health hazard assessment. Radioprotection 51(1), 47-50 (2016). 